\title{
THE GREAT DIVERGENCE
}


THE PRINCETON ECONOMIC HISTORY

OF THE WESTERN WORLD

Joel Mokyr, Editor

Growth in a Traditional Society: The French Countryside, 1450-1815, by Philip T. Hoffman

The Vanishing Irish: Households, Migration, and the Rural Economy in Ireland, 1850-1914, by Timothy W. Guinnane

Black '47 and Beyond: The Great Irish Famine in History, Economy, and Memory, by Cormac Ó Gráda

The Great Divergence: China, Europe, and the Making of the Modern World Economy, by Kenneth Pomeranz 


\title{
THE GREAT DIVERGENCE
}

\author{
CHINA, EUROPE, AND \\ THE MAKING OF \\ THE MODERN WORLD ECONOMY
}

Kenneth Pomeranz

With a new preface by the author 
COPYRIGHT @ 2000 BY PRINCETON UNIVERSITY PRESS

PREFACE TO THE PRINCETON CLASSICS EDITION COPYRIGHT @ 2021 BY PRINCETON UNIVERSITY PRESS

PUBLISHED BY PRINCETON UNIVERSITY PRESS, 41 WILLIAM STREET,

PRINCETON, NEW JERSEY 08540

IN THE UNITED KINGDOM: PRINCETON UNIVERSITY PRESS, 6 OXFORD STREET, WOODSTOCK, OXFORDSHIRE OX20 1TR COVER ART: WORLD MAP, 1871 / ISTOCK COVER DESIGN: MICHAEL BOLAND

ALL RIGHTS RESERVED

FIRST PAPERBACK PRINTING, 2001

FIRST PRINCETON CLASSICS PAPERBACK EDITION,

WITH A NEW PREFACE BY THE AUTHOR, 2021

NEW PAPERBACK ISBN 9780691217185

LIBRARY OF CONGRESS CONTROL NUMBER: 2020949716

THIS BOOK HAS BEEN COMPOSED IN TIMES ROMAN

PRESS.PRINCETON.EDU

PRINTED IN THE UNITED STATES OF AMERICA 